\title{
A retrospective study of infections after primary VP shunt placement in the newborn with Myelomeningocele without prophylactic antibiotics
}

\author{
Dorte Clemmensen ${ }^{*}$, Mikkel Mylius Rasmussen, Claus Mosdal \\ From 54th Annual Meeting of the Society for Research into Hydrocephalus and Spina Bifida \\ Vancouver, Canada. 7-10 July 2010
}

\section{Background}

We aim to correlate the frequency of infections after VP shunt placement in neonates with myelomeningocele (MMC) who did not receive prophylactic antibiotics, to the timing of VP shunt placement and the frequency of Cerebrospinal fluid (CSF)leakage at the MMC wound.

\section{Materials and methods}

59 newborns with MMC underwent VP shunt insertion in the period 1983-2007. We reviewed retrospectively all records.

\section{Results}

The relative risk (RR (95\%)) of having an infection is significant higher $\mathrm{RR}=4,69(1.145397-19.23568)(\mathrm{P}=$ .03761817)and neuroinfection showed a tendency towards $: \mathrm{RR}=3.5(.7067445-17.03112)(\mathrm{P}=.15414095)$ in newborns without symptomatic Hydrocephalus at birth when we had a wait and watch policy (late shunt placement) compared to newborns with prompt shunt placement. The relative risk (RR 95\%) of having a infection was highly significant: $R R=6,8(3.314154-13.95228)$ $(\mathrm{P}=1.235 \mathrm{e}-07)$ and also neuroinfections $\mathrm{RR}=4,76$ $(2.043019-11.09025)(\mathrm{P}=.00044478)$ if the child presented MMC wound CSF leakage before VP shunt insertion.

\section{Conclusions}

Centres with a conservative antibiotic policy should be even more careful to avoid CSF leakage before shunt

\footnotetext{
* Correspondence: dorcle@rm.dk

Department of Neurosurgery, Aarhus University Hospital, Canada
}

placement as this gives a highly significant increased risk of both infections in total and neuroinfections and they should reconsider this conservative policy in newborns with MMC due to the significant high infections rate.

Published: 15 December 2010

doi:10.1186/1743-8454-7-S1-S43

Cite this article as: Clemmensen et al:: A retrospective study of infections after primary VP shunt placement in the newborn with Myelomeningocele without prophylactic antibiotics. Cerebrospinal Fluid Research 2010 7(Suppl 1):S43.

Submit your next manuscript to BioMed Central and take full advantage of:

- Convenient online submission

- Thorough peer review

- No space constraints or color figure charges

- Immediate publication on acceptance

- Inclusion in PubMed, CAS, Scopus and Google Scholar

- Research which is freely available for redistribution

Submit your manuscript at www.biomedcentral.com/submit
() Biomed Central 